\title{
Proteomic Analysis of Mouse Brain Subjected to Spaceflight
}

\author{
Xiao Wen Mao ${ }^{1}{ }^{\circledR}$, Lawrence B. Sandberg ${ }^{2}$, Daila S. Gridley ${ }^{1}$, E. Clifford Herrmann ${ }^{2}$,

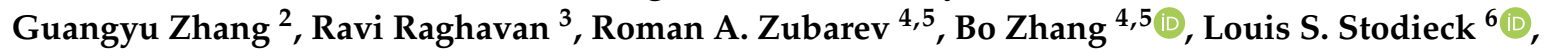 \\ Virginia L. Ferguson ${ }^{6}$, Ted A. Bateman ${ }^{7}$ and Michael J. Pecaut ${ }^{1, *(1)}$ \\ 1 Department of Basic Sciences, Division of Biomedical Engineering Sciences, Loma Linda University School \\ of Medicine, Loma Linda, CA 92354, USA; xmao@llu.edu (X.W.M.); dgridley@llu.edu (D.S.G.) \\ 2 Department of Biochemistry, Loma Linda University School of Medicine, Loma Linda, CA 92350, USA; \\ lsandberg@llu.edu (L.B.S.); cherrmann@llu.edu (E.C.H.); guangyuzhang@llu.edu (G.Z.) \\ 3 Department of Pathology and Human Anatomy, Loma Linda University School of Medicine, Loma Linda, \\ CA 92350, USA; rraghavan@llu.edu \\ 4 Department of Medical Biochemistry and Biophysics, Biomedicum, Karolinska Institutet, SE 17177 \\ Stockholm, Sweden; Roman.Zubarev@ki.se (R.A.Z.); Bo.Zhang@ki.se (B.Z.) \\ 5 Department of Pharmacological and Technological Chemistry, I.M. Sechenov First Moscow State Medical \\ University, Moscow 119991, Russia \\ 6 BioServe Space Technologies, University of Colorado at Boulder, Boulder, CO 80303, USA; \\ stodieck@colorado.edu (L.S.S.); Virginia.Ferguson@colorado.edu (V.L.F.) \\ 7 Department of Bioengineering, University of North Carolina at Chapel Hill, Chapel Hill, NC 27599, USA; \\ tbateman@email.unc.edu \\ * Correspondence: mpecaut@llu.edu; Tel./Fax: +1-909-558-8372
}

Received: 9 November 2018; Accepted: 17 December 2018; Published: 20 December 2018

\begin{abstract}
There is evidence that spaceflight poses acute and late risks to the central nervous system. To explore possible mechanisms, the proteomic changes following spaceflight in mouse brain were characterized. Space Shuttle Atlantis (STS-135) was launched from the Kennedy Space Center (KSC) on a 13-day mission. Within 3-5 h after landing, brain tissue was collected to evaluate protein expression profiles using quantitative proteomic analysis. Our results showed that there were 26 proteins that were significantly altered after spaceflight in the gray and/or white matter. While there was no overlap between the white and gray matter in terms of individual proteins, there was overlap in terms of function, synaptic plasticity, vesical activity, protein/organelle transport, and metabolism. Our data demonstrate that exposure to the spaceflight environment induces significant changes in protein expression related to neuronal structure and metabolic function. This might lead to a significant impact on brain structural and functional integrity that could affect the outcome of space missions.
\end{abstract}

Keywords: brain; spaceflight; microgravity; proteomics

\section{Introduction}

Long-term deep space missions expose astronauts to an environment that is characterized mainly by ultraviolet and ionizing radiation, microgravity, and physiological/psychological stressors. These conditions present a significant hazard to spaceflight crews during and after the course of mission activities. The hazards posed to normal tissues, such as the central nervous system (CNS), are not fully understood. The health risks of spaceflight-induced neuronal damage and potential neurodegenerative effects have long been a concern. Brain damage and degeneration can be promoted by many 
factors including aging, ischemia, fluctuation in oxygen tension, oxidative stress, and increased intraocular pressure.

There is some evidence that low-dose, space-relevant radiation induces changes in neuronal functions [1]. Microgravity induces intraocular pressure and vascular changes [2,3] and promotes apoptosis of astrocytes [4]. Spaceflight also induces cognitive and perceptual motor performance deterioration under stress [5]. Studies have shown that exposure to spaceflights has a strong impact on metabolic and stress response [6]. Collective evidence indicates that exposure to stressful spaceflight environments might induce changes in brain neuronal structure and function. However, the pathophysiological consequences and role of cellular mechanisms of stress stimuli, especially those stemming from the spaceflight environment, in facilitating brain damage and neurodegeneration have been studied less and remain unclear.

Gray matter consists of neurons (i.e., it contains the cell bodies, dendrites and axon terminals of neurons), nerve fibers, astrocytes, microglia, and capillaries. Gray matter is closely associated with the functional domains of performance, locomotion, learning, memory and coordination. On the other hand, white matter consists mostly of oligodendroglial cells, myelinated axons and capillaries. White matter allows communication to and from gray matter areas, and between gray matter and the other parts of the body. It functions by transmitting the information from the different parts of the body towards the cerebral cortex. It modulates the distribution of action potentials, acting as a relay and coordinating communication between different brain regions [7]. Changes in gray matter are known to be primarily associated with Alzheimer's disease and other neurodegenerative diseases, with secondary effects on the white matter [8]. The deficits range from language ability to delayed memory and visuospatial construction. Disrupted white matter organization has been linked to poorer motor performance [9]. Studies have shown altered expressions of a number of genes and proteins involving a wide spectrum of biological functions following exposure to space environments. These alterations induced distinct changes specific to the regions of the brain [10]. Regional difference in stress response was also documented following simulated microgravity in human brain gray matter and white matter [11].

The purpose of the present investigation was to study spaceflight condition-induced changes in protein expression profiles in mouse gray matter and to compare these changes to those in white matter regions. Our unique data might provide new insights and improve risk assessment for future long-term space travel.

\section{Results}

There were nine and 17 proteins that were significantly altered after spaceflight in the white (Table 1 ) and gray (Table 2$)$ matter, respectively $(p<0.05$, log fold change $>1.0$ or $<-1.0)$. In general, proteins that were significantly altered were upregulated in both areas of the brain. However, there was no overlap between the brain area data sets. If log fold change constraints were reduced to $>0.5$, the number of proteins increased to 16 and 25 for white and gray matter, respectively.

There were no significant changes in canonical pathways or upstream regulators in the pathway analysis for either the white or gray matter proteins. However, there were strong trends for changes in functionally related proteins in both brain regions (Table 3). In the white matter, there was a strong trend for a downregulation of functions related to the formation of cellular protrusions $(Z=-1.98)$. In the gray matter, there was a significant downregulation of functions related to overall organismal death and organ degeneration $(Z<-2.0)$. There were also strong trends for downregulation in cellular and neural degenerative functions $(Z=-1.98)$. Interestingly, there was a significant upregulation in functions related to viral infection $(Z>2.0)$. 
Table 1. Spaceflight induced alterations to the proteomic profile in the white matter.

\begin{tabular}{|c|c|c|c|c|c|}
\hline Symbol & Entrez Gene Name & Expr $p$-Value & Expr Log Ratio & Location & Type(s) \\
\hline ARG1 & arginase 1 & 0.037 & 3.742 & Cytoplasm & enzyme \\
\hline CACNA2D1 & calcium voltage-gated channel auxiliary subunit alpha2delta 1 & 0.024 & 2.244 & Plasma Membrane & ion channel \\
\hline PPFIA3 & PTPRF interacting protein alpha 3 & 0.025 & 2.189 & Plasma Membrane & phosphatase \\
\hline PITPNA & phosphatidylinositol transfer protein alpha & 0.010 & 1.328 & Cytoplasm & transporter \\
\hline MYO5A & myosin VA & 0.034 & 1.304 & Cytoplasm & enzyme \\
\hline DYNLL2 & dynein light chain LC8-type 2 & 0.040 & 1.152 & Cytoplasm & other \\
\hline VPS35 & VPS35, retromer complex component & 0.046 & -1.164 & Cytoplasm & transporter \\
\hline GAPDH & glyceraldehyde-3-phosphate dehydrogenase & 0.015 & -1.478 & Cytoplasm & enzyme \\
\hline MBP & myelin basic protein & 0.003 & -2.536 & Extracellular Space & other \\
\hline
\end{tabular}

Table 2. Spaceflight induced alterations to the proteomic profile in the gray matter.

\begin{tabular}{|c|c|c|c|c|c|}
\hline Symbol & Entrez Gene Name & Expr $p$-Value & Expr Log Ratio & Location & Type(s) \\
\hline QDPR & quinoid dihydropteridine reductase & 0.0229 & 2.458 & Cytoplasm & enzyme \\
\hline DNM3 & dynamin 3 & 0.00186 & 1.781 & Cytoplasm & enzyme \\
\hline ACAT1 & acetyl-CoA acetyltransferase 1 & 0.0000214 & 1.637 & Cytoplasm & enzyme \\
\hline DNAJC5 & DnaJ heat shock protein family (Hsp40) member C5 & 0.00702 & 1.501 & Plasma Membrane & other \\
\hline SH3GL2 & SH3 domain containing GRB2-like 2, endophilin A1 & 0.0136 & 1.377 & Plasma Membrane & enzyme \\
\hline RAP1GDS1 & Rap1 GTPase-GDP dissociation stimulator 1 & 0.0284 & 1.363 & Cytoplasm & other \\
\hline DNM1L & dynamin 1-like & 0.0069 & 1.284 & Cytoplasm & enzyme \\
\hline CNP & $2^{\prime}, 3^{\prime}$-cyclic nucleotide $3^{\prime}$ phosphodiesterase & 0.000816 & 1.261 & Cytoplasm & enzyme \\
\hline YWHAE & tyrosine 3-monooxygenase/tryptophan 5-monooxygenase activation protein epsilon & 0.00989 & 1.261 & Cytoplasm & other \\
\hline ACTN1 & actinin alpha 1 & 0.0308 & 1.254 & Cytoplasm & transcription regulator \\
\hline ATP6V0A1 & ATPase $\mathrm{H}+$ transporting V0 subunit a1 & 0.00028 & 1.191 & Cytoplasm & transporter \\
\hline IMMT & inner membrane mitochondrial protein & 0.00436 & 1.154 & Cytoplasm & other \\
\hline NEFL & neurofilament light & 0.00557 & 1.153 & Cytoplasm & other \\
\hline ENO2 & enolase 2 & 0.0281 & 1.123 & Cytoplasm & enzyme \\
\hline STX1A & syntaxin $1 \mathrm{~A}$ & 0.00859 & 1.074 & Cytoplasm & transporter \\
\hline UQCRB & ubiquinol-cytochrome $\mathrm{c}$ reductase binding protein & 0.0447 & -1.059 & Cytoplasm & enzyme \\
\hline SEC22B & SEC22 homolog B, vesicle trafficking protein (gene/pseudogene) & 0.00601 & -2.709 & Cytoplasm & other \\
\hline
\end{tabular}


Table 3. Spaceflight induced changes in white and gray matter proteins indicative of functional deficits.

\begin{tabular}{|c|c|c|c|c|}
\hline Region & Categories & Diseases or Functions Annotation & $p$-Value & Activation Z-Score \\
\hline \multirow[t]{11}{*}{ White Matter } & Cell Morphology, Cellular Assembly and Organization, Cellular Function and Maintenance & formation of cellular protrusions & $1.69 \times 10^{-3}$ & -1.982 \\
\hline & Organismal Survival & organismal death & $3.76 \times 10^{-2}$ & -1.156 \\
\hline & Cellular Assembly and Organization, Cellular Function and Maintenance & organization of cytoplasm & $6.40 \times 10^{-5}$ & -1.154 \\
\hline & Cellular Assembly and Organization, Cellular Function and Maintenance & microtubule dynamics & $9.47 \times 10^{-5}$ & -1.154 \\
\hline & Tissue Morphology & quantity of cells & $3.44 \times 10^{-2}$ & -0.44 \\
\hline & Cell Death and Survival & apoptosis & $4.26 \times 10^{-2}$ & 0.003 \\
\hline & Cell Death and Survival & necrosis & $1.41 \times 10^{-2}$ & 0.014 \\
\hline & Cell Death and Survival & cell death of tumor cell lines & $4.40 \times 10^{-3}$ & 0.028 \\
\hline & Cell Death and Survival & cell death & $1.41 \times 10^{-2}$ & 0.166 \\
\hline & Cell Death and Survival & apoptosis of tumor cell lines & $3.86 \times 10^{-2}$ & 0.176 \\
\hline & Lipid Metabolism, Molecular Transport, Small Molecule Biochemistry & concentration of lipid & $7.47 \times 10^{-3}$ & 0.333 \\
\hline \multirow[t]{12}{*}{ Gray Matter } & Organismal Survival & organismal death & $1.22 \times 10^{-3}$ & -3.257 \\
\hline & Organismal Injury and Abnormalities & organ degeneration & $1.46 \times 10^{-5}$ & -2.186 \\
\hline & Cellular Compromise & degeneration of cells & $1.36 \times 10^{-4}$ & -1.982 \\
\hline & Developmental Disorder & growth failure & $1.45 \times 10^{-2}$ & -1.982 \\
\hline & Neurological Disease & neurodegeneration & $8.36 \times 10^{-5}$ & -1.981 \\
\hline & Cell Death and Survival & necrosis & $1.84 \times 10^{-5}$ & -1.6 \\
\hline & Cell Death and Survival & apoptosis & $5.78 \times 10^{-3}$ & -1.404 \\
\hline & Cell Death and Survival & neuronal cell death & $2.96 \times 10^{-3}$ & -0.958 \\
\hline & Molecular Transport & transport of molecule & $9.80 \times 10^{-3}$ & -0.722 \\
\hline & Cell Death and Survival & cell viability & $1.48 \times 10^{-2}$ & 0.555 \\
\hline & Infectious Diseases & infection by HIV-1 & $2.45 \times 10^{-3}$ & 1.98 \\
\hline & Infectious Diseases & Viral Infection & $1.12 \times 10^{-2}$ & 2.2 \\
\hline
\end{tabular}




\section{Discussion}

While there do not appear to be enough significantly different proteins in either white or gray matter in this analysis to appear as a significantly activated canonical pathway, there still appear to be common functional themes: (1) synaptic function, (2) intracellular communication, (3) metabolism, (4) oxidative stress and tissue damage responses, and (5) activation of catecholamines.

\subsection{Synaptic Function: Plasticity, Vesicles and Dendritic Spines}

In the white matter there were three proteins related to synaptic plasticity that were upregulated. Calcium voltage-gated channel auxiliary subunit $\alpha 2 \delta 1$ (CACNA2D1) is intimately involved in calcium channel trafficking [12] and regulates excitatory synapse formation during development or after injury [13]. PTPRF interacting protein $\alpha 3$ (PPFIA3, also known as Liprin- $\alpha-3$ ) is typically found to be co-expressed with a variety of pre-synaptic proteins in neurons but has also been found in astrocytes [14,15]. It is thought to be involved in presynaptic plasticity and synaptic vesicle release, particularly in excitatory synapses $[15,16]$. Myosin VA (MYO5A) is an F-actin-based motor protein that is also important in the generation and movement of synaptic vesicles. It has been found in dendritic spines and synaptic vesicles and appears to be critical for synaptic plasticity and organelle transport (reviewed in Reference [17]).

Several proteins associated with synaptic function that are upregulated in the gray matter after flight involve vesicle formation, exocytosis and endocytosis. Syntaxin 1A (STX1A) is a soluble $\mathrm{N}$-ethylmaleimide-sensitive fusion attachment protein receptor (SNARE) protein that is expressed in most neurons [18] and is a critical component of synaptic vesicle formation and exocytosis [19,20]. DNAJ heat shock protein family (Hsp40) member C5 (DNAJC5) is a pre-synaptic DNAJ C-class Hsp40 co-chaperone that is primarily expressed in the brain and retina (reviewed in [21]). It is part of a complex of proteins that resides on synaptic vesicles and chaperones pre-synaptic SNARE proteins, making it critical during repeated synaptic vesicle cycles [22]. Indeed, DNAJC5 knockout mice have progressive, age-dependent sensorimotor deficits and the protein appears to be critical to preventing pre-synaptic degeneration via deficits in endocytosis [21,23].

Upregulated within gray matter, dynamin 3 (DNM3) is expressed in the dendritic spines and is primarily associated with regulating synaptic vesicle endocytosis and recycling [24-26]. There are three isoforms of dynamin that share about $80 \%$ overall homology and have mostly redundant roles in clathrin-mediated endocytosis and membrane fission [24,27]. The SH3 domain containing GRB2-like 2, endophilin A1 (SH3GL2, also known as endophilin-1) is a potential tumor suppressor gene [28] that is highly expressed in the brain, particularly in presynaptic ganglion [29]. However, the primary function of this protein is to regulate clathrin-mediated endocytosis (reviewed in [30]). Finally, while not directly related to neuronal communication, ATPase $\mathrm{H}+$ transporting V0 subunit A1 (ATP6V0A1) involves a form of endocytosis in microglia. This protein that was upregulated in gray matter, is involved with the merging of lysosomes and phagosomes during phagocytosis in the brain [31]. Interestingly, clathrin-mediated endocytosis was significantly and highly upregulated in the liver of these mice as well [32], suggesting a systemic response.

In addition to vesicle formation, several of the proteins upregulated in gray matter after spaceflight have been implicated in neurite and dendritic spine formation. Tyrosine 3-monooxygenase/tryptophan 5-monooxygenase activation protein epsilon (YWHAE) is believed to play a critical role during neuronal development and migration [33] and neurite formation during cortical development [34]. Over expression of this gene disrupts neurite formation through the microtubule binding protein, doublecortin [34]. Enolase 2 (ENO2) has also been shown to have neurotrophic activity [35] and is involved in cytoskeletal remodeling and neurite regeneration [36].

Similarly, both dynamin 3 (DNM3) [37] and SH3 domain containing GRB2-like 2, endophilin A1 (SH3GL2) [38] that were upregulated in gray matter are involved with dendritic spine morphogenesis and stability. Another upregulated protein in the gray matter is actinin alpha 1 (ACTN1). Expressed in the dendritic spines of the post-synaptic density (PSD) [39,40], this protein is an actin-crosslinking 
protein [41] that is involved with synaptic plasticity [39]. This is interesting because changes in dendrite activity might be related to synaptic plasticity $[42,43]$.

Consistent with the upregulation of proteins related to neurite and dendrite growth is the downregulation of SEC22B (SEC22 homolog B, a vesicle trafficking protein) in the gray matter. Knocking down this protein using siRNA reduced neurite length had no impact on neuronal migration [44].

\subsection{Intracellular Communication: Myelination and Protein/Organelle Transport}

Another broad category impacted by spaceflight is involved in intracellular communication. Specifically, (1) axonal signaling that is "insulated" via myelin and (2) protein and organelle transport. Downregulated in the murine white matter, myelin basic protein (MBP) has an important role in the process of myelination of axons, particularly in the adhesion of myelin layers between cytosolic surfaces $[45,46]$. MBP is implicated in auto-immune responses within the human CNS, and is thought to be a target for $\mathrm{T}$ cell activity in multiple sclerosis and other demyelinating or degenerative disorders. Its reduction over an extended period is usually associated with glial inflammation activation and proliferation, leading to reactive astrocytosis [47,48].

Interestingly, three important factors found in oligodendrocytes and involved in myelin formation were upregulated in the gray matter: acyl-coenzyme A, a cholesterol acyltransferase 1 (ACAT1) [49]; $2^{\prime}, 3^{\prime}$-cyclic nucleotide $3^{\prime}$-phosphodiesterase (CNP) [50,51]; and neurofilament light (NEFL) [52,53].

Two components of protein/organelle transport were upregulated in the white matter. As stated previously, myosin VA (MYO5A) is important for organelle transport (reviewed in Reference [17]). Similarly, dynein light chain LC8-type 2 (DYNLL2, also known as DLC2), originally identified as part of the microtubule-based motor protein dynein [54], is involved with transporting mitochondria along the axons of neurons in response to local energy and metabolic requirements [55]. However, DYNLL2 has also been shown to have a variety of other targets including nNOS, post synaptic scaffolding proteins, and pro-apoptotic proteins [54].

However, there were also two factors involved in protein transport that were downregulated in white matter. Vacuolar protein sorting 35 ortholog (VPS35) is a component of the "cargo recognition complex" of the retromer complex responsible for the retrograde transport of proteins from endosomes to the trans-Golgi network or the plasma membrane [56,57]. Already mentioned above as an important component of myelin, MBP also interacts with the cytoskeleton and/or tight junctions, making it critical for communicating extracellular signaling to the inside of the cell [46]. Decreases in MBP have been associated with glial activation [58].

\subsection{Metabolism: Glycolysis and Mitochondrial Function}

Consistent with our previous results, in the liver and skin of the same mice in which we found that spaceflight had a major impact on metabolism [32,59,60], the next broad category involved the impact of spaceflight on the brain, including glycolysis and metabolism.

Two proteins involved in glycolysis or metabolism were altered by spaceflight in the white matter. This first one was upregulated. Phosphatidylinositol transfer protein $\alpha$ (PITPNA) is involved with coordinating lipid metabolism and signaling [61], transferring phospholipids out of the endoplasmic reticulum and into other membranes [62]. Interestingly, an increase in oxidative stress has been shown to cause a decrease in this protein, particularly in the brains of aged or Parkinson's disease models [63]. This lack has been associated with neurodegenerative disease, which has been linked to changes in glucose homeostasis [64]. Glyceraldehyde-3-phosphate dehydrogenase (GAPDH) is an abundant enzyme in brain tissue that is critical to energy metabolism and glycolysis [65]. In conditions of oxidative stress, GAPDH activity is impaired, leading to cellular aging and apoptosis [65]. This enzyme can undergo sulfhydration, S-nitrosylation and oxidation, which, in turn, can lead to memory loss, apoptotic cell death and neurodegeneration, noted in ischemia and Alzheimer's disease models [66-68]. 
In the gray matter, enolase 2 (ENO2) was upregulated after flight, also suggesting glycolysis may be impacted. ENO2 is a glycolytic enzyme [69] found in neurons, neuroendocrine cells and microglia $[69,70]$. However, one of the few proteins that were downregulated in the gray matter, SEC22B (SEC22 homolog B, vesicle trafficking protein), also complexes with SNARE proteins in the endoplasmic reticulum (ER) [44,71]. Knocking down this protein using siRNA had no impact on exocytosis [44]. Instead, SEC22B interacted with lipid transfer proteins, a factor which, when inhibited, has been shown to result in changes in lipid metabolism and transfer [44].

Simultaneously, four proteins critical to mitochondrial function were also upregulated in the gray matter. The mitochondrial localized enzyme, acetyl-CoA acetyltransferase 1 (ACAT1), has been linked to cholesterol homeostasis and metabolism [72,73] and can be found in axons of the cerebral cortex and hippocampus [49]. Dynamin 1-like (DNM1L) is critical to mitochondrial fission [74]. This protein drives mitochondrial division by self-assembling into filaments that constrict around the organelle [75]. The 2', $3^{\prime}$-cyclic nucleotide $3^{\prime}$-phosphodiesterase (CNP) can also be found in the inner membranes of mitochondria [76] and is important for $\mathrm{Ca}^{2+}$ transport [77]. Interestingly CNP levels decreased in non-synaptic mitochondria in the brains of old rats [77]. An increase in CNP release suggests mitochondria may be in a calcium-overloaded condition [78]. Inner membrane mitochondrial protein (IMMT), also known as MIC60 and mitofilin, is important for protein translocation across the mitochondrial membrane, regulating both morphology and protein biogenesis [79].

Even though the tissues were collected and prepared for analysis less than five hours after landing, it is possible that the changes in proteins related to metabolism are simply a response to the landing and do not reflect changes in the spaceflight environment. To confirm or deny this possibility would require that mice be euthanized in orbit and tissues immediately preserved for analysis on the ground. Indeed, such studies have already been planned. However, in our previous study examining the livers of these same mice, there were significant changes in lipid metabolism indicative of a pre-diabetic state that seems to suggest a long-term effect rather than an acute response due to landing $[32,59,80]$.

\subsection{Oxidative Stress and Tissue Damage Responses}

The changes noted in metabolism are likely related to increases in proteins involved with oxidative stress and inflammation in the white matter. Arginase 1 (ARG1), which was highly upregulated, is an important enzyme of the urea cycle that is generally found in the liver and is critical to removing ammonia from the body [81]. However, ARG1+ is also commonly expressed by alternatively-activated macrophages and microglia [82], which tend to be anti-inflammatory. In the brain, ARG1+ microglia have been implicated in amyloid beta plaque removal [83]. Furthermore, it is important to nitric oxide (NO)-mediated vasodilation in microvascular endothelial cells [84]. In activated macrophages, ARG1+ competes with NO synthase (NOS) for their common substrate, L-arginine, leading to a reduction in NO production [85].

Not surprisingly, many of the mitochondrial proteins that were upregulated in the gray matter are also involved in the oxidative stress response. ACAT1 expression has been shown to be elevated during conditions of oxidative stress [49]. Mutations in DNM1L often result in death associated with oxidative stress-induced neurodegeneration $[75,86]$. In vitro, deleting DNML1 from Purkinje cells resulted in increased oxidative damage via the peroxidation of proteins and lipids [75]. Decreases in IMMT appear to result in increases in ROS levels [87] and seem to be an anti-apoptotic protein important for the regulation of cytochrome c release [87-89]. Interestingly, the oxidative damage due to lipid peroxidation found in the interfibrillar mitochondria of diabetic heart tissue was reduced by overexpressing IMMT [90,91].

Increases in the above oxidative stress factors are consistent with the decreases noted in another mitochondrial protein, UQCRB (ubiquinol-cytochrome $\mathrm{c}$ reductase binding protein), a subunit of complex III in the mitochondrial respiratory chain [92] of the gray matter. UQCRB is important in mediating mitochondrial-derived reactive oxygen species (ROS) that are both independent of NADPH 
oxidase and important for angiogenesis [93]. Drugs which inhibit the activity of UQCRB reduce the ROS produced by the mitochondria [92-94].

Although not found in mitochondria, Quinonoid dihydropteridine reductase (QDPR) is also upregulated in the gray matter. QDPR is primarily associated with the regeneration of tetrahydrobiopterin (BH4) from quinonoid dihydrobiopterin (qBH2). This is important because $\mathrm{BH} 4$ is a critical co-factor in the generation of all three NO synthases, iNOS, nNOS, and eNOS [95]. In quinonoid dihydropteridine reductase (QDPR) $)^{-/-}$knockout mice, the biomarkers of folate-dependent oxidative stress such as ophthalamate, spermine, and $\gamma$-Glu-Cys all appeared to be elevated [95].

Given the changes in markers indicative of oxidative stress, it should not be surprising that there were also changes in proteins related to cell damage and death. In the gray matter, at least four upregulated proteins dealing with intracellular damage and/or cell death appeared to be involved. This is consistent with the IPA analysis that found changes in proteins related to organismal death, degeneration of cells, and neurodegeneration. ATP6V0A1 is critically important in mediating autophagosome-lysosome fusion [96]. DNAJC5 appears to have some influence on protein folding and endosomal autophagy, depending on the presence of SGT and Hsc70 [97]. ACAT1 is instrumental in induction of necroptosis through lipid droplet formation that has been demonstrated to be the initial key event in cell death [98]. Finally, CNP appears to play a role with caspase-independent apoptosis [99].

\subsection{Activation of Catecholamines}

Finally, there were several changes in the white matter involved in sympathetic activity and catecholamine production. As mentioned previously, CACNA2D1 was upregulated in the white matter. Although we did not specifically look at areas within the brain, this protein is active in the periventricular nucleus (PVN) and is involved with sympathetic outflow [13]. This is interesting because two proteins involved with sympathetic responses were also upregulated in the gray matter. Quinonoid dihydropteridine reductase (QDPR) is primarily associated with the regeneration of tetrahydrobiopterin (BH4) from quinonoid dihydrobiopterin (qBH2). $\mathrm{BH} 4$ is a critical co-factor in the biosynthesis of the neurotransmitters dopamine and serotonin [95]. Syntaxin 1A (STX1A) is expressed in endocrine cells [18] and STX1A knockout mice had decreased circulating levels of the stress hormones, $\mathrm{CRH}$ and $\mathrm{ACTH}$, as well as serotonergic precursors [18].

\section{Materials and Methods}

\subsection{STS-135 Flight Mice and Control Conditions}

Space Shuttle Atlantis, i.e., Space Transportation System 135 (STS-135), was launched from the Kennedy Space Center (KSC) on a 13-day mission in July of 2011. Female C57BL/ 6 mice (Charles River Laboratories, Inc., Hollister, CA, USA) were flown in STS-135 using NASA's animal enclosure modules (AEMs). Mice were housed in two groups of five per AEM, separated by mesh wire. A set of ground controls (Ground AEMs) was housed at the Space Life Science Laboratory (SLSL) at the KSC. Ground AEM control mice were placed into the same housing hardware used in flight and environmental parameters such as temperature and carbon dioxide $\left(\mathrm{CO}_{2}\right)$ levels were matched as closely as possible based on 48-h delayed telemetry data.

All mice were under ambient temperatures of $26-28^{\circ} \mathrm{C}$ with a 12 -h day/night cycle during the flight. The mid deck $\mathrm{CO}_{2}$ levels that the mice were exposed to averaged 2150 parts per million (ppm) and ranged from a few hundred ppm while on the ground, before installation in the shuttle, to a maximum level of $3480 \mathrm{ppm}$ in the shuttle during the mission. AEM controls were fed a special NASA food bar diet, the same as the space-flown mice. All mice received the same access to food and water ad libitum.

The Loma Linda University (LLU) Institutional Animal Care and Use Committee (IACUC) was consulted but no protocol was required since tissues were only obtained after euthanasia. However, it 
should be noted that all NASA research with vertebrate animals is done in strict accordance with the recommendations in the Guide for the Care and Use of Laboratory Animals of the National Institute of Health (NIH). The primary science team responsible for running the project obtained approval from the NASA Ames Research Center ACUC (NAS-11-002-Y1) on 5/31/2011.

Upon return to Earth, animals were removed from the AEM nursing facility and assessed for survival and health. It was reported that all the mice survived the 13-day space mission. All animals were described by the inspecting personnel as being in good condition.

\subsection{Dissection and Preservation of Mouse Brains Post Flight}

Within $3-5 \mathrm{~h}$ after landing, the mice were euthanized and the brains were removed (4-8 mice/group). As part of the primary science, all mice underwent dual energy X-ray absorptiometry (DEXA) densitometry (Piximus, Inc., Fitchburg, WI, USA) immediately prior to anesthesia and euthanasia. Mice were anesthetized with 3-5\% isoflurane and euthanized with $100 \% \mathrm{CO}_{2}$ and exsanguination via cardiac puncture. The whole brain hemispheres were fixed in $4 \%$ paraformaldehyde in phosphate buffered saline (PBS) for $24 \mathrm{~h}$ and then rinsed with PBS and infiltrated overnight with $30 \%$ sucrose in PBS at $4{ }^{\circ} \mathrm{C}$. Fixed samples were sent to Loma Linda University (LLU) via courier for analysis. As we were part of the NASA Biospecimen Sharing Program (BSP) team, we did not have access to all the tissues from all the mice. However, we received tissues from four flight mice and eight ground control mice. Tissue from two of the ground control samples were lost during processing, giving us a final sample size of $n=4$ or 6 for flight and ground, respectively.

\subsection{Brain Sectioning for Proteomic Analysis}

Paraffin-embedded brain sections were coronally gross sectioned at a thickness of $10 \mu \mathrm{m}$. After mounting and de-paraffinizing, six $3 \mathrm{~mm}$ diameter circular punches of tissue were obtained to provide three replicate samples each of white matter of the corpus callosum and gray matter of the cerebral cortex. Each tissue punch (disk) was transferred to a vial for individual processing (work up) by a modification of the methodology of Craven et al. [100]. When tissues are processed by the Craven method, formalin fixed tissues still yield $80 \%$ or more of the available proteins for proteomic analyses [100]. The preparation of the tissue samples for proteomic mass spectrometry (MS) analysis in this paper is described by the steps below.

\subsection{Protein Extraction from Tissue}

We used boil-proof $1.7 \mathrm{~mL}$ low retention polypropylene snap-top vials to process the tissues. Lysis buffer was made by combining $50 \mu \mathrm{L}$ each of stock solutions A and B, plus $10 \mu \mathrm{L}$ of freshly prepared 1.1 M dithiothreitol (DTT). Solution A consisted of $300 \mathrm{mM}$ Tris- $\mathrm{Cl}$ pH 8.2. Solution B was made by combining five liquid components: $20 \%$ sodium dodecyl sulfate (SDS), glycerol, trifluorethanol, thiodiethanol, and water at the volumetric ratio of 3:2:1:1:3. Protein extraction was initiated by the addition of $110 \mu \mathrm{L}$ lysis buffer to each vial containing a tissue punch (disk), followed by incubation for $30 \mathrm{~min}$ at $105^{\circ} \mathrm{C}$ in a fume hood because of trifluorethanol toxicity. After cooling the vials were stored indefinitely at $-80^{\circ} \mathrm{C}$.

\subsection{Trypsin Digestion}

This was done using Amicon Ultra-0.5 mL $30 \mathrm{kDa}$ centrifugal filter devices (http://www. emdmillipore.com). A urea-ammonium bicarbonate buffer (UA) that is $50 \mathrm{mM}$ with respect to ammonium bicarbonate ( $\mathrm{ABC}$ ) and $8 \mathrm{M}$ with respect to ultrapure urea (https: / / www.thermofisher.com) was prepared fresh on the day of use. The use of the Amicon Ultra centrifugal filter device has been outlined next. (a) To each vial after protein extraction (see above) $300 \mu \mathrm{L}$ of UA were added and vortexed. The sample components were transferred to an Amicon Ultra, centrifuged at $10,000 \times g$ for $10 \mathrm{~min}$, and the filtrate was discarded. (b) To complete the transfer initiated above and to continue the replacement of reagents from the protein extraction procedure described in 2.4 above with UA 
constituents, the above process was repeated twice using $400 \mu \mathrm{L}$ UA each time, and both filtrates were discarded. (c) Next, $5 \mu \mathrm{L}$ each of $5 \mathrm{mM}$ Tris (2-carboxyethyl) phosphine (TCEP) and $10 \mathrm{mM}$ acrylamide and $200 \mu \mathrm{L}$ UA were combined. The entire volume was then transferred to the Amicon Ultra, incubated for $30 \mathrm{~min}$ at ambient temperatures, centrifuged, and the filtrate was discarded. (d) The reagents were washed by the addition of $400 \mu \mathrm{L} \mathrm{UA}$, centrifuged, and the filtrate was discarded. (e) The urea was washed out by the addition of $400 \mu \mathrm{L}$ of $50 \mathrm{mM} \mathrm{ABC}$, centrifuged, and the filtrate was discarded. This process was repeated twice more. (f) Next, $200 \mu \mathrm{L}$ of $50 \mathrm{mM} \mathrm{ABC}$ were added and a protein assay (Nanodrop, http:/ /www.nanodrop.com, or Micro BCA, http:/ / www.thermofisher.com) was performed on an aliquot. (g) A prepared trypsin digestion solution was added to the remaining protein in the Amicon Ultra. The $100 \mu \mathrm{L}$ of $250 \mathrm{mM} \mathrm{ABC}$ were combined with $2.5 \mu \mathrm{L}$ of $1 \%$ Promega PMax (http:/ / promega.com) to give a $0.025 \%$ working solution plus sufficient sequencer-grade trypsin to result in an enzyme to protein ratio in the range of 1:25-50. (h) The solution was incubated overnight at $37^{\circ} \mathrm{C}$ to convert the proteins to peptides. (i) The next morning, $150 \mu \mathrm{L}$ of water was added, centrifuged, and the filtrate containing the peptides was collected. These steps were repeated using another $150 \mu \mathrm{L}$ water and the filtrates were combined. (j) Next, $20 \mu \mathrm{L}$ of $10 \%$ TFA were added to the combined filtrates to destroy the PMax. (k) The filtrate was concentrated in a vacuum centrifuge to a volume of $100 \mu \mathrm{L}$ and stored at $-80^{\circ} \mathrm{C}$. (l) Just prior to MS analysis, a 2-5 $\mu$ g portion of each protein/peptide sample was purified with a Zip-tip C18 P10 (http:/ / www.emdmillipore.com). The sample preparations from each set of the three replicate "punches" were pooled, resulting in a total of 20 samples for MS analysis.

\subsection{MS Analyses and Data Processing}

An Easy-nLC system with an autosampler was attached to an LTQ-Orbitrap Velos Pro mass spectrometer (http:/ / thermoscientificbio.com). This was used for all MS analyses utilizing 2 to $2.5 \mu \mathrm{g}$ peptide loadings after zip-tip purification. After injection, the $5 \mu \mathrm{L}$ peptide samples in $0.25 \%$ TFA were passed through a $2 \mathrm{~cm} \times 100 \mu \mathrm{m} \mathrm{C18}$, of $5 \mu \mathrm{m}$ particle size, precolumn (http:/ / thermoscientificbio.com) in series with a $10 \mathrm{~cm} \times 75 \mu \mathrm{m}$ in-house-prepared capillary column packed with Microm Magic C18 of $5 \mu$ particle size (http:/ / www.michrom.com/) for separation and elution.

A 2-h gradient was used (Solvent A 0.1\% FA in water, Solvent B 0.1\% FA in ACN, 5-30\% Solvent B). Collision-induced disassociation was used to fragment the top 10 most abundant ions and the MS/MS spectra were collected between 250 and $1500 \mathrm{~m} / z$, following the parent full-scan mass spectrum collected at 60,000 resolution.

The raw data files from these analyses were processed first through Proteome Discoverer (http: // thermoscientificbio.com) for precursor intensity with the following search parameters using the mouse Uniprot/Swissprot database: 2 missed trypsin cleavages allowed, dynamic oxidation on methionine, deamidation on asparagine and glutamine, and static proprionamide attachment on cysteine. In parallel, the data processing was performed using our DeMix Q algorithm. Briefly, DeMix "unmixes" the MS/MS events that become frequently but accidentally multiplexed because more than one (up to four) precursor ions are selected for fragmentation within the same $m / z$ window simultaneously [101]. DeMix allows one to identify more peptides on average than there were precursors selected for MS/MS. For extension of the peptide identity "between the runs" and thus additionally increase the number of identified peptides while simultaneously improving quantification accuracy, we used DeMix Q [102], an extension of the DeMix algorithm that employs the scoring of identity transfer. Further improvement in quantification accuracy can be achieved with the help of our Diffacto algorithm [103] that selects for protein quantification of only "well-behaved" peptides.

All spread sheets with protein relative abundances were then exported into Ingenuity Pathway Analysis (IPA; http://www.ingenuity.com/products/ipa). In IPA, only direct relationships were allowed in the general settings and genes. Endogenous chemical interactions and causal networks were both included. All items were selected under data sources, confidence, species and mutation. 


\section{Conclusions}

In summary, this study is the first to identify spaceflight-induced proteomic significance and biomarkers in the gray and white matter of the murine brain. These unique "proteomic signatures" of brain tissue may provide new mechanistic insight into the complex biological response to space environment. We propose that spaceflight conditions induce changes in neuronal structure, cellular function, oxidative response, mitochondrial function and metabolism, which, in turn, might lead to tissue injury and late neurodegeneration. The diverse changes in protein expression profiles in white and gray matter in response to spaceflight conditions warrants further investigation. Further studies are also necessary to elucidate the possible tissue and functional impact responsible for our findings and to identify effective countermeasures.

Author Contributions: X.W.M., M.J.P., D.S.G., V.L.F. and T.A.B. conceived and designed the experiments; X.W.M., M.J.P., L.S.S., V.L.F., T.A.B., L.B.S., E.C.H. and G.Z. performed the experiments; R.A.Z., B.Z., and M.J.P. analyzed the data; L.S.S., V.L.F., T.A.B., R.A.Z., and B.Z. contributed reagents/materials/analysis tools; X.W.M., L.B.S., R.S., and M.J.P. wrote the paper.

Funding: This study was supported by NASA managed cooperative agreement NNX10AJ31G, NASA Grant NNX13AN34G, and the LLUMC Departments of Biomedical Engineering Sciences and Radiation Medicine.

Acknowledgments: This study would not have been possible without the support of Amgen, Inc. and their team. In addition, we very much appreciate BioServe Space Technologies at the University of Colorado at Boulder for organizing and overseeing this project. We also thank the Ferguson, Bateman and Bouxsein lab members for helping with tissue collection at Kennedy Space Center (KSC). The staff at Ames Research Center and KSC Space Life Sciences Laboratory (SLSL), as well as Paula Dumars and Vera Vizir of the NASA Biospecimen Sharing Program (BSP), contributed significantly to the success of our study and we greatly appreciate their support.

Conflicts of Interest: The authors declare no conflict of interest. The funders had no role in the design of the study; in the collection, analyses, or interpretation of data; in the writing of the manuscript, and in the decision to publish the results.

\section{References}

1. Rudobeck, E.; Nelson, G.A.; Sokolova, I.V.; Vlkolinsky, R. (28)silicon radiation impairs neuronal output in CA1 neurons of mouse ventral hippocampus without altering dendritic excitability. Radiat. Res. 2014, 181, 407-415. [CrossRef] [PubMed]

2. Woo, S.J.; Kim, T.W.; Chung, K.Y. Intraocular pressure elevation during space flight. J. Glaucoma 2012, 21, 349. [CrossRef] [PubMed]

3. Mader, T.H.; Gibson, C.R.; Caputo, M.; Hunter, N.; Taylor, G.; Charles, J.; Meehan, R.T. Intraocular pressure and retinal vascular changes during transient exposure to microgravity. Am. J. Ophthalmol. 1993, 115, 347-350. [CrossRef]

4. Uva, B.M.; Masini, M.A.; Sturla, M.; Tagliafierro, G.; Strollo, F. Microgravity-induced programmed cell death in astrocytes. J. Gravit. Physiol. A J. Int. Soc. Gravit. Physiol. 2002, 9, P275-P276.

5. De la Torre, G.G. Cognitive neuroscience in space. Life 2014, 4, 281-294. [CrossRef] [PubMed]

6. Strollo, F.; Vassilieva, G.; Ruscica, M.; Masini, M.; Santucci, D.; Borgia, L.; Magni, P.; Celotti, F.; Nikiporuc, I. Changes in stress hormones and metabolism during a 105-day simulated Mars mission. Aviat. Spaceand Environ. Med. 2014, 85, 793-797. [CrossRef] [PubMed]

7. Fields, R.D. White matter matters. Sci. Am. 2008, 298, 42-49.

8. Mortamais, M.; Artero, S.; Ritchie, K. White matter hyperintensities as early and independent predictors of Alzheimer's disease risk. J. Alzheimers Dis. 2014, 42 (Suppl. 4), S393-S400. [CrossRef]

9. Gooijers, J.; Chalavi, S.; Beeckmans, K.; Michiels, K.; Lafosse, C.; Sunaert, S.; Swinnen, S.P. Subcortical Volume Loss in the Thalamus, Putamen, and Pallidum, Induced by Traumatic Brain Injury, Is Associated with Motor Performance Deficits. Neurorehabil. Neural Repair 2016, 30, 603-614. [CrossRef]

10. Santucci, D.; Kawano, F.; Ohira, T.; Terada, M.; Nakai, N.; Francia, N.; Alleva, E.; Aloe, L.; Ochiai, T.; Cancedda, R.; et al. Evaluation of gene, protein and neurotrophin expression in the brain of mice exposed to space environment for 91 days. PLoS ONE 2012, 7, e40112. [CrossRef] 
11. Li, K.; Guo, X.; Jin, Z.; Ouyang, X.; Zeng, Y.; Feng, J.; Wang, Y.; Yao, L.; Ma, L. Effect of Simulated Microgravity on Human Brain Gray Matter and White Matter-Evidence from MRI. PLoS ONE 2015, 10, e0135835. [CrossRef] [PubMed]

12. Dolphin, A.C. Calcium channel auxiliary $\alpha 2 \delta$ and $\beta$ subunits: Trafficking and one step beyond. Nat. Rev. Neurosci. 2012, 13, 542-555. [CrossRef] [PubMed]

13. Eroglu, C.; Allen, N.J.; Susman, M.W.; O’Rourke, N.A.; Park, C.Y.; Ozkan, E.; Chakraborty, C.; Mulinyawe, S.B.; Annis, D.S.; Huberman, A.D.; et al. Gabapentin receptor $\alpha 2 \delta-1$ is a neuronal thrombospondin receptor responsible for excitatory CNS synaptogenesis. Cell 2009, 139, 380-392. [CrossRef] [PubMed]

14. Spangler, S.A.; Jaarsma, D.; De Graaff, E.; Wulf, P.S.; Akhmanova, A.; Hoogenraad, C.C. Differential expression of liprin- $\alpha$ family proteins in the brain suggests functional diversification. J. Comp. Neurol. 2011, 519, 3040-3060. [CrossRef] [PubMed]

15. Torres, V.I.; Inestrosa, N.C. Vertebrate Presynaptic Active Zone Assembly: A Role Accomplished by Diverse Molecular and Cellular Mechanisms. Mol. Neurobiol. 2017. [CrossRef] [PubMed]

16. Dai, Y.; Taru, H.; Deken, S.L.; Grill, B.; Ackley, B.; Nonet, M.L.; Jin, Y. SYD-2 Liprin- $\alpha$ organizes presynaptic active zone formation through ELKS. Nat. Neurosci. 2006, 9, 1479-1487. [CrossRef] [PubMed]

17. Wollert, T.; Patel, A.; Lee, Y.L.; Provance, D.W., Jr.; Vought, V.E.; Cosgrove, M.S.; Mercer, J.A.; Langford, G.M. Myosin5a tail associates directly with Rab3A-containing compartments in neurons. J. Biol. Chem. 2011, 286, 14352-14361. [CrossRef] [PubMed]

18. Fujiwara, T.; Kofuji, T.; Akagawa, K. Dysfunction of the hypothalamic-pituitary-adrenal axis in STX1A knockout mice. J. Neuroendocrinol. 2011, 23, 1222-1230. [CrossRef]

19. Jahn, R.; Hanson, P.I. Membrane fusion. SNAREs line up in new environment. Nature 1998, 393, 14-15. [CrossRef]

20. Sudhof, T.C. The synaptic vesicle cycle: A cascade of protein-protein interactions. Nature 1995, 375, 645-653. [CrossRef]

21. Gorenberg, E.L.; Chandra, S.S. The Role of Co-chaperones in Synaptic Proteostasis and Neurodegenerative Disease. Front. Neurosci. 2017, 11, 248. [CrossRef] [PubMed]

22. Sharma, M.; Burre, J.; Sudhof, T.C. CSP $\alpha$ promotes SNARE-complex assembly by chaperoning SNAP-25 during synaptic activity. Nat. Cell Biol. 2011, 13, 30-39. [CrossRef] [PubMed]

23. Fernandez-Chacon, R.; Wolfel, M.; Nishimune, H.; Tabares, L.; Schmitz, F.; Castellano-Munoz, M.; Rosenmund, C.; Montesinos, M.L.; Sanes, J.R.; Schneggenburger, R.; et al. The synaptic vesicle protein CSP $\alpha$ prevents presynaptic degeneration. Neuron 2004, 42, 237-251. [CrossRef]

24. Raimondi, A.; Ferguson, S.M.; Lou, X.; Armbruster, M.; Paradise, S.; Giovedi, S.; Messa, M.; Kono, N.; Takasaki, J.; Cappello, V.; et al. Overlapping role of dynamin isoforms in synaptic vesicle endocytosis. Neuron 2011, 70, 1100-1114. [CrossRef] [PubMed]

25. Tanifuji, S.; Funakoshi-Tago, M.; Ueda, F.; Kasahara, T.; Mochida, S. Dynamin isoforms decode action potential firing for synaptic vesicle recycling. J. Biol. Chem. 2013, 288, 19050-19059. [CrossRef] [PubMed]

26. Fan, F.; Funk, L.; Lou, X. Dynamin 1- and 3-Mediated Endocytosis Is Essential for the Development of a Large Central Synapse In Vivo. J. Neurosci. Off. J. Soc. Neurosci. 2016, 36, 6097-6115. [CrossRef]

27. Cao, H.; Garcia, F.; McNiven, M.A. Differential distribution of dynamin isoforms in mammalian cells. Mol. Biol. Cell 1998, 9, 2595-2609. [CrossRef] [PubMed]

28. Qu, S.; Yao, Y.; Shang, C.; Xue, Y.; Ma, J.; Li, Z.; Liu, Y. MicroRNA-330 is an oncogenic factor in glioblastoma cells by regulating SH3GL2 gene. PLoS ONE 2012, 7, e46010. [CrossRef]

29. Giachino, C.; Lantelme, E.; Lanzetti, L.; Saccone, S.; Bella Valle, G.; Migone, N. A novel SH3-containing human gene family preferentially expressed in the central nervous system. Genomics 1997, 41, 427-434. [CrossRef]

30. Reutens, A.T.; Begley, C.G. Endophilin-1: A multifunctional protein. Int. J. Biochem. Cell Biol. 2002, 34, 1173-1177. [CrossRef]

31. Peri, F.; Nusslein-Volhard, C. Live imaging of neuronal degradation by microglia reveals a role for v0-ATPase a1 in phagosomal fusion in vivo. Cell 2008, 133, 916-927. [CrossRef] [PubMed]

32. Pecaut, M.J.; Mao, X.W.; Bellinger, D.L.; Jonscher, K.R.; Stodieck, L.S.; Ferguson, V.L.; Bateman, T.A.; Mohney, R.P.; Gridley, D.S. Is spaceflight-induced immune dysfunction linked to systemic changes in metabolism? PLoS ONE 2017, 12, e0174174. [CrossRef] [PubMed] 
33. Toyo-oka, K.; Shionoya, A.; Gambello, M.J.; Cardoso, C.; Leventer, R.; Ward, H.L.; Ayala, R.; Tsai, L.H.; Dobyns, W.; Ledbetter, D.; et al. 14-3-3epsilon is important for neuronal migration by binding to NUDEL: A molecular explanation for Miller-Dieker syndrome. Nat. Genet. 2003, 34, 274-285. [CrossRef] [PubMed]

34. Cornell, B.; Wachi, T.; Zhukarev, V.; Toyo-Oka, K. Regulation of neuronal morphogenesis by 14-3-3epsilon (Ywhae) via the microtubule binding protein, doublecortin. Hum. Mol. Genet. 2016, 25, 4405-4418. [CrossRef] [PubMed]

35. Hafner, A.; Obermajer, N.; Kos, J. $\gamma$-1-syntrophin mediates trafficking of $\gamma$-enolase towards the plasma membrane and enhances its neurotrophic activity. Neurosignals 2010, 18, 246-258. [CrossRef] [PubMed]

36. Hafner, A.; Obermajer, N.; Kos, J. $\gamma$-Enolase C-terminal peptide promotes cell survival and neurite outgrowth by activation of the PI3K/Akt and MAPK/ERK signalling pathways. Biochem. J. 2012, 443, 439-450. [CrossRef] [PubMed]

37. Gray, N.W.; Kruchten, A.E.; Chen, J.; McNiven, M.A. A dynamin-3 spliced variant modulates the actin/cortactin-dependent morphogenesis of dendritic spines. J. Cell Sci. 2005, 118, 1279-1290. [CrossRef]

38. Yang, Y.; Wei, M.; Xiong, Y.; Du, X.; Zhu, S.; Yang, L.; Zhang, C.; Liu, J.J. Endophilin A1 regulates dendritic spine morphogenesis and stability through interaction with p140Cap. Cell Res. 2015, 25, 496-516. [CrossRef] [PubMed]

39. Wyszynski, M.; Kharazia, V.; Shanghvi, R.; Rao, A.; Beggs, A.H.; Craig, A.M.; Weinberg, R.; Sheng, M. Differential regional expression and ultrastructural localization of $\alpha$-actinin-2, a putative NMDA receptor-anchoring protein, in rat brain. J. Neurosci. Off. J. Soc. Neurosci. 1998, 18, 1383-1392. [CrossRef]

40. Walikonis, R.S.; Oguni, A.; Khorosheva, E.M.; Jeng, C.J.; Asuncion, F.J.; Kennedy, M.B. Densin-180 forms a ternary complex with the $\alpha$-subunit of $\mathrm{Ca}^{2+} /$ calmodulin-dependent protein kinase II and $\alpha$-actinin. J. Neurosci. Off. J. Soc. Neurosci. 2001, 21, 423-433. [CrossRef]

41. Waites, G.T.; Graham, I.R.; Jackson, P.; Millake, D.B.; Patel, B.; Blanchard, A.D.; Weller, P.A.; Eperon, I.C.; Critchley, D.R. Mutually exclusive splicing of calcium-binding domain exons in chick $\alpha$-actinin. J. Biol. Chem. 1992, 267, 6263-6271. [PubMed]

42. Labno, A.; Warrier, A.; Wang, S.; Zhang, X. Local plasticity of dendritic excitability can be autonomous of synaptic plasticity and regulated by activity-based phosphorylation of Kv4.2. PLoS ONE 2014, 9, e84086. [CrossRef] [PubMed]

43. Sjostrom, P.J.; Rancz, E.A.; Roth, A.; Hausser, M. Dendritic excitability and synaptic plasticity. Physiol. Rev. 2008, 88, 769-840. [CrossRef] [PubMed]

44. Petkovic, M.; Jemaiel, A.; Daste, F.; Specht, C.G.; Izeddin, I.; Vorkel, D.; Verbavatz, J.M.; Darzacq, X.; Triller, A.; Pfenninger, K.H.; et al. The SNARE Sec22b has a non-fusogenic function in plasma membrane expansion. Nat. Cell Biol. 2014, 16, 434-444. [CrossRef] [PubMed]

45. Wong, J.H.; Halliday, G.M.; Kim, W.S. Exploring myelin dysfunction in multiple system atrophy. Exp. Neurobiol. 2014, 23, 337-344. [CrossRef] [PubMed]

46. Boggs, J.M. Myelin basic protein: A multifunctional protein. Cell. Mol. Life Sci. 2006, 63, $1945-1961$. [CrossRef]

47. Kuhlmann, T.; Ludwin, S.; Prat, A.; Antel, J.; Bruck, W.; Lassmann, H. An updated histological classification system for multiple sclerosis lesions. Acta Neuropathol. 2017, 133, 13-24. [CrossRef]

48. Gallart-Palau, X.; Serra, A.; Lee, B.S.T.; Guo, X.; Sze, S.K. Brain ureido degenerative protein modifications are associated with neuroinflammation and proteinopathy in Alzheimer's disease with cerebrovascular disease. J. Neuroinflamm. 2017, 14, 175. [CrossRef]

49. Kim, J.H.; Ee, S.M.; Jittiwat, J.; Ong, E.S.; Farooqui, A.A.; Jenner, A.M.; Ong, W.Y. Increased expression of acyl-coenzyme A: Cholesterol acyltransferase-1 and elevated cholesteryl esters in the hippocampus after excitotoxic injury. Neuroscience 2011, 185, 125-134. [CrossRef]

50. Hinman, J.D.; Chen, C.D.; Oh, S.Y.; Hollander, W.; Abraham, C.R. Age-dependent accumulation of ubiquitinated 2',3'-cyclic nucleotide 3'-phosphodiesterase in myelin lipid rafts. Glia 2008, 56, 118-133. [CrossRef]

51. Sprinkle, T.J. 2',3'-cyclic nucleotide 3'-phosphodiesterase, an oligodendrocyte-Schwann cell and myelin-associated enzyme of the nervous system. Crit. Rev. Neurobiol. 1989, 4, 235-301. [PubMed] 
52. Rao, M.V.; Houseweart, M.K.; Williamson, T.L.; Crawford, T.O.; Folmer, J.; Cleveland, D.W. Neurofilament-dependent radial growth of motor axons and axonal organization of neurofilaments does not require the neurofilament heavy subunit (NF-H) or its phosphorylation. J. Cell Biol. 1998, 143, 171-181. [CrossRef] [PubMed]

53. Monteiro, M.J.; Hoffman, P.N.; Gearhart, J.D.; Cleveland, D.W. Expression of NF-L in both neuronal and nonneuronal cells of transgenic mice: Increased neurofilament density in axons without affecting caliber. J. Cell Biol. 1990, 111, 1543-1557. [CrossRef]

54. Wagner, W.; Fodor, E.; Ginsburg, A.; Hammer, J.A., 3rd. The binding of DYNLL2 to myosin Va requires alternatively spliced exon B and stabilizes a portion of the myosin's coiled-coil domain. Biochemistry 2006, 45, 11564-11577. [CrossRef] [PubMed]

55. Chen, Y.M.; Gerwin, C.; Sheng, Z.H. Dynein light chain LC8 regulates syntaphilin-mediated mitochondrial docking in axons. J. Neurosci. Off. J. Soc. Neurosci. 2009, 29, 9429-9438. [CrossRef] [PubMed]

56. Williams, E.T.; Chen, X.; Moore, D.J. VPS35, the Retromer Complex and Parkinson's Disease. J. Parkinsons Dis. 2017, 7, 219-233. [CrossRef]

57. Trousdale, C.; Kim, K. Retromer: Structure, function, and roles in mammalian disease. Eur. J. Cell Biol. 2015, 94, 513-521. [CrossRef] [PubMed]

58. Ou-Yang, M.H.; Van Nostrand, W.E. The absence of myelin basic protein promotes neuroinflammation and reduces amyloid $\beta$-protein accumulation in Tg-5xFAD mice. J. Neuroinflamm. 2013, 10, 134. [CrossRef] [PubMed]

59. Jonscher, K.R.; Alfonso-Garcia, A.; Suhalim, J.L.; Orlicky, D.J.; Potma, E.O.; Ferguson, V.L.; Bouxsein, M.L.; Bateman, T.A.; Stodieck, L.S.; Levi, M.; et al. Spaceflight activates lipotoxic pathways in mouse liver. PLoS ONE 2016, 11, e0152877. [CrossRef]

60. Mao, X.W.; Pecaut, M.J.; Stodieck, L.S.; Ferguson, V.L.; Bateman, T.A.; Bouxsein, M.L.; Gridley, D.S. Biological and metabolic response in STS-135 space-flown mouse skin. Free Radic. Res. 2014, 48, 890-897. [CrossRef] [PubMed]

61. Alb, J.G., Jr.; Phillips, S.E.; Wilfley, L.R.; Philpot, B.D.; Bankaitis, V.A. The pathologies associated with functional titration of phosphatidylinositol transfer protein $\alpha$ activity in mice. J. Lipid Res. 2007, 48, 1857-1872. [CrossRef] [PubMed]

62. Liscovitch, M.; Cantley, L.C. Signal transduction and membrane traffic: The PITP/phosphoinositide connection. Cell 1995, 81, 659-662. [CrossRef]

63. Chalimoniuk, M.; Snoek, G.T.; Adamczyk, A.; Malecki, A.; Strosznajder, J.B. Phosphatidylinositol transfer protein expression altered by aging and Parkinson disease. Cell. Mol. Neurobiol. 2006, 26, 1153-1166. [CrossRef]

64. Alb, J.G., Jr.; Cortese, J.D.; Phillips, S.E.; Albin, R.L.; Nagy, T.R.; Hamilton, B.A.; Bankaitis, V.A. Mice lacking phosphatidylinositol transfer protein- $\alpha$ exhibit spinocerebellar degeneration, intestinal and hepatic steatosis, and hypoglycemia. J. Biol. Chem. 2003, 278, 33501-33518. [CrossRef] [PubMed]

65. Nicholls, C.; Li, H.; Liu, J.P. GAPDH: A common enzyme with uncommon functions. Clin. Exp. Pharm. Physiol. 2012, 39, 674-679. [CrossRef] [PubMed]

66. Mir, S.; Sen, T.; Sen, N. Cytokine-induced GAPDH sulfhydration affects PSD95 degradation and memory. Mol. Cell 2014, 56, 786-795. [CrossRef] [PubMed]

67. Li, C.; Feng, J.J.; Wu, Y.P.; Zhang, G.Y. Cerebral ischemia-reperfusion induces GAPDH S-nitrosylation and nuclear translocation. Biochemistry 2012, 77, 671-678. [CrossRef]

68. Butterfield, D.A.; Hardas, S.S.; Lange, M.L. Oxidatively modified glyceraldehyde-3-phosphate dehydrogenase (GAPDH) and Alzheimer's disease: Many pathways to neurodegeneration. J. Alzheimers Dis. 2010, 20, 369-393. [CrossRef]

69. Schmechel, D.E.; Marangos, P.J.; Martin, B.M.; Winfield, S.; Burkhart, D.S.; Roses, A.D.; Ginns, E.I. Localization of neuron-specific enolase (NSE) mRNA in human brain. Neurosci. Lett. 1987, 76, 233-238. [CrossRef]

70. Hafner, A.; Glavan, G.; Obermajer, N.; Zivin, M.; Schliebs, R.; Kos, J. Neuroprotective role of gamma-enolase in microglia in a mouse model of Alzheimer's disease is regulated by cathepsin X. Aging Cell 2013, 12, 604-614. [CrossRef]

71. Joglekar, A.P.; Hay, J.C. Evidence for regulation of ER/Golgi SNARE complex formation by hsc70 chaperones. Eur. J. Cell Biol. 2005, 84, 529-542. [CrossRef] [PubMed] 
72. Lee, O.; Chang, C.C.; Lee, W.; Chang, T.Y. Immunodepletion experiments suggest that acyl-coenzyme A:cholesterol acyltransferase-1 (ACAT-1) protein plays a major catalytic role in adult human liver, adrenal gland, macrophages, and kidney, but not in intestines. J. Lipid Res. 1998, 39, 1722-1727. [PubMed]

73. Ong, W.Y.; Kim, J.H.; He, X.; Chen, P.; Farooqui, A.A.; Jenner, A.M. Changes in brain cholesterol metabolome after excitotoxicity. Mol. Neurobiol. 2010, 41, 299-313. [CrossRef] [PubMed]

74. Fahrner, J.A.; Liu, R.; Perry, M.S.; Klein, J.; Chan, D.C. A novel de novo dominant negative mutation in DNM1L impairs mitochondrial fission and presents as childhood epileptic encephalopathy. Am. J. Med. Genet. A 2016, 170, 2002-2011. [CrossRef] [PubMed]

75. Zhang, Z.; Kageyama, Y.; Sesaki, H. Mitochondrial division prevents neurodegeneration. Autophagy 2012, 8 , 1531-1533. [CrossRef] [PubMed]

76. Azarashvili, T.; Krestinina, O.; Galvita, A.; Grachev, D.; Baburina, Y.; Stricker, R.; Evtodienko, Y.; Reiser, G. $\mathrm{Ca}^{2+}$-dependent permeability transition regulation in rat brain mitochondria by $2^{\prime}, 3^{\prime}$-cyclic nucleotides and 2',3'-cyclic nucleotide 3'-phosphodiesterase. Am. J. Physiol. Cell Physiol. 2009, 296, C1428-C1439. [CrossRef] [PubMed]

77. Krestinina, O.; Azarashvili, T.; Baburina, Y.; Galvita, A.; Grachev, D.; Stricker, R.; Reiser, G. In aging, the vulnerability of rat brain mitochondria is enhanced due to reduced level of $2^{\prime}, 3^{\prime}$-cyclic nucleotide-3'-phosphodiesterase (CNP) and subsequently increased permeability transition in brain mitochondria in old animals. Neurochem. Int. 2015, 80, 41-50. [CrossRef]

78. Baburina, Y.; Odinokova, I.; Azarashvili, T.; Akatov, V.; Lemasters, J.J.; Krestinina, O. 2',3'-Cyclic nucleotide $3^{\prime}$-phosphodiesterase as a messenger of protection of the mitochondrial function during melatonin treatment in aging. Biochim. Biophys. Acta 2017, 1859, 94-103. [CrossRef]

79. Von der Malsburg, K.; Muller, J.M.; Bohnert, M.; Oeljeklaus, S.; Kwiatkowska, P.; Becker, T.; Loniewska-Lwowska, A.; Wiese, S.; Rao, S.; Milenkovic, D.; et al. Dual role of mitofilin in mitochondrial membrane organization and protein biogenesis. Dev. Cell 2011, 21, 694-707. [CrossRef]

80. Blaber, E.A.; Pecaut, M.J.; Jonscher, K.R. Spaceflight Activates Autophagy Programs and the Proteasome in Mouse Liver. Int. J. Mol. Sci. 2017, 18, 2062. [CrossRef]

81. Sin, Y.Y.; Baron, G.; Schulze, A.; Funk, C.D. Arginase-1 deficiency. J. Mol. Med. 2015, 93, 1287-1296. [CrossRef] [PubMed]

82. Munder, M.; Eichmann, K.; Moran, J.M.; Centeno, F.; Soler, G.; Modolell, M. Th1/Th2-regulated expression of arginase isoforms in murine macrophages and dendritic cells. J. Immunol. 1999, 163, 3771-3777. [PubMed]

83. Cherry, J.D.; Olschowka, J.A.; O’Banion, M.K. Arginase 1+ microglia reduce A $\beta$ plaque deposition during IL-1 $\beta$-dependent neuroinflammation. J. Neuroinflamm. 2015, 12, 203. [CrossRef] [PubMed]

84. Zhang, C.; Hein, T.W.; Wang, W.; Chang, C.I.; Kuo, L. Constitutive expression of arginase in microvascular endothelial cells counteracts nitric oxide-mediated vasodilatory function. Faseb J. Off. Publ. Fed. Am. Soc. Exp. Biol. 2001, 15, 1264-1266. [CrossRef]

85. Chang, C.I.; Liao, J.C.; Kuo, L. Arginase modulates nitric oxide production in activated macrophages. Am. J. Physiol. 1998, 274, H342-H348. [CrossRef] [PubMed]

86. Reddy, P.H.; Reddy, T.P.; Manczak, M.; Calkins, M.J.; Shirendeb, U.; Mao, P. Dynamin-related protein 1 and mitochondrial fragmentation in neurodegenerative diseases. Brain Res. Rev. 2011, 67, 103-118. [CrossRef] [PubMed]

87. John, G.B.; Shang, Y.; Li, L.; Renken, C.; Mannella, C.A.; Selker, J.M.; Rangell, L.; Bennett, M.J.; Zha, J. The mitochondrial inner membrane protein mitofilin controls cristae morphology. Mol. Biol. Cell 2005, 16, 1543-1554. [CrossRef] [PubMed]

88. Yang, R.F.; Zhao, G.W.; Liang, S.T.; Zhang, Y.; Sun, L.H.; Chen, H.Z.; Liu, D.P. Mitofilin regulates cytochrome $\mathrm{c}$ release during apoptosis by controlling mitochondrial cristae remodeling. Biochem. Biophys. Res. Commun. 2012, 428, 93-98. [CrossRef] [PubMed]

89. Barrera, M.; Koob, S.; Dikov, D.; Vogel, F.; Reichert, A.S. OPA1 functionally interacts with MIC60 but is dispensable for crista junction formation. FEBS Lett. 2016, 590, 3309-3322. [CrossRef] [PubMed]

90. Dabkowski, E.R.; Williamson, C.L.; Bukowski, V.C.; Chapman, R.S.; Leonard, S.S.; Peer, C.J.; Callery, P.S.; Hollander, J.M. Diabetic cardiomyopathy-associated dysfunction in spatially distinct mitochondrial subpopulations. Am. J. Physiol. Heart Circ. Physiol. 2009, 296, H359-H369. [CrossRef] [PubMed] 
91. Thapa, D.; Nichols, C.E.; Lewis, S.E.; Shepherd, D.L.; Jagannathan, R.; Croston, T.L.; Tveter, K.J.; Holden, A.A.; Baseler, W.A.; Hollander, J.M. Transgenic overexpression of mitofilin attenuates diabetes mellitus-associated cardiac and mitochondria dysfunction. J. Mol. Cell. Cardiol. 2015, 79, 212-223. [CrossRef] [PubMed]

92. Jung, H.J.; Shim, J.S.; Lee, J.; Song, Y.M.; Park, K.C.; Choi, S.H.; Kim, N.D.; Yoon, J.H.; Mungai, P.T.; Schumacker, P.T.; et al. Terpestacin inhibits tumor angiogenesis by targeting UQCRB of mitochondrial complex III and suppressing hypoxia-induced reactive oxygen species production and cellular oxygen sensing. J. Biol. Chem. 2010, 285, 11584-11595. [CrossRef] [PubMed]

93. Jung, H.J.; Kim, Y.; Chang, J.; Kang, S.W.; Kim, J.H.; Kwon, H.J. Mitochondrial UQCRB regulates VEGFR2 signaling in endothelial cells. J. Mol. Med. 2013, 91, 1117-1128. [CrossRef] [PubMed]

94. Chang, J.; Jung, H.J.; Park, H.J.; Cho, S.W.; Lee, S.K.; Kwon, H.J. Cell-permeable mitochondrial ubiquinol-cytochrome c reductase binding protein induces angiogenesis in vitro and in vivo. Cancer Lett. 2015, 366, 52-60. [CrossRef] [PubMed]

95. Xu, F.; Sudo, Y.; Sanechika, S.; Yamashita, J.; Shimaguchi, S.; Honda, S.; Sumi-Ichinose, C.; Mori-Kojima, M.; Nakata, R.; Furuta, T.; et al. Disturbed biopterin and folate metabolism in the Qdpr-deficient mouse. FEBS Lett. 2014, 588, 3924-3931. [CrossRef] [PubMed]

96. Hsin, I.L.; Sheu, G.T.; Jan, M.S.; Sun, H.L.; Wu, T.C.; Chiu, L.Y.; Lue, K.H.; Ko, J.L. Inhibition of lysosome degradation on autophagosome formation and responses to GMI, an immunomodulatory protein from Ganoderma microsporum. Br. J. Pharmacol. 2012, 167, 1287-1300. [CrossRef] [PubMed]

97. Uytterhoeven, V.; Lauwers, E.; Maes, I.; Miskiewicz, K.; Melo, M.N.; Swerts, J.; Kuenen, S.; Wittocx, R.; Corthout, N.; Marrink, S.J.; et al. Hsc70-4 Deforms Membranes to Promote Synaptic Protein Turnover by Endosomal Microautophagy. Neuron 2015, 88, 735-748. [CrossRef]

98. Yamanaka, K.; Urano, Y.; Takabe, W.; Saito, Y.; Noguchi, N. Induction of apoptosis and necroptosis by 24(S)-hydroxycholesterol is dependent on activity of acyl-CoA:cholesterol acyltransferase 1. Cell Death Dis. 2014, 5, e990. [CrossRef]

99. Baburina, Y.; Azarashvili, T.; Grachev, D.; Krestinina, O.; Galvita, A.; Stricker, R.; Reiser, G. Mitochondrial 2', 3'-cyclic nucleotide 3'-phosphodiesterase (CNP) interacts with mPTP modulators and functional complexes (I-V) coupled with release of apoptotic factors. Neurochem. Int. 2015, 90, 46-55. [CrossRef]

100. Craven, R.A.; Vasudev, N.S.; Banks, R.E. Proteomics and the search for biomarkers for renal cancer. Clin. Biochem. 2013, 46, 456-465. [CrossRef]

101. Zhang, B.; Pirmoradian, M.; Chernobrovkin, A.; Zubarev, R.A. DeMix workflow for efficient identification of cofragmented peptides in high resolution data-dependent tandem mass spectrometry. Mol. Cell. Proteom. MCP 2014, 13, 3211-3223. [CrossRef] [PubMed]

102. Zhang, B.; Kall, L.; Zubarev, R.A. DeMix-Q: Quantification-Centered Data Processing Workflow. Mol. Cell. Proteom. MCP 2016, 15, 1467-1478. [CrossRef] [PubMed]

103. Zhang, B.; Pirmoradian, M.; Zubarev, R.; Kall, L. Covariation of Peptide Abundances Accurately Reflects Protein Concentration Differences. Mol. Cell. Proteom. MCP 2017, 16, 936-948. [CrossRef] [PubMed]

(C) 2018 by the authors. Licensee MDPI, Basel, Switzerland. This article is an open access article distributed under the terms and conditions of the Creative Commons Attribution (CC BY) license (http://creativecommons.org/licenses/by/4.0/). 